\title{
PRODUCTIVITY OF CORN HYBRIDS IN RELATION TO SOWING OVERLAP
}

\author{
Marcelo S. de Farias $^{1 *}$, Ravel F. Dagios², Antônio L. Santi', Maurício R. Cherubin ${ }^{3}$
}

${ }^{1 *}$ Corresponding author. Universidade Federal de Santa Maria - Campus de Frederico Westphalen/ Frederico Westphalen - RS, Brasil. E-mail: silveira_farias@hotmail.com | ORCID ID: https://orcid.org/0000-0002-2949-1320

\section{KEYWORDS}

Zea mays, precision agriculture, section control, plant population.

\begin{abstract}
The automatic control of section shut-off in seed drills minimizes seeding overlap and can reduce productivity losses, especially in responsive crops such as corn. In that context, this study evaluated the effect of sowing overlap on the grain yield and productivity of three corn hybrids. A DB-50 precision seed drill, with 33 rows equipped with a 16-row automatic section control, was used in this experiment. A randomized block design was applied to test three corn hybrids under two sowing conditions (without sowing overlap WOSO; and with sowing overlap - WSO), with four replications. The analyzed variables were the number of plants per hectare, the number of cobs per hectare, cob length, the number of grains per cob, the thousand grain weight, and productivity. WOSO areas presented cobs that were larger and had more grains, as well as a higher thousand grain weight, resulting in a productivity $13 \%$ higher than that of WSO areas. Therefore, the use of automatic section control is a technically feasible alternative to reduce seed costs and avoid productivity losses in corn crops.
\end{abstract}

\section{INTRODUCTION}

Globalization and the competitiveness of the Brazilian market both demand a highly efficient agricultural production process, leading rural entrepreneurs to seek productivity-increasing strategies, streamlining the use of supplies and, consequently, reducing production costs (Farias et al., 2018). Within this context, the use of precision agriculture tools has been contributing to a higher, more efficient, and more sustainable production (Santi et al., 2013; Miranda et al., 2017).

In Brazil, corn crops (Zea mays) account for 17.7 million hectares: 4.9 million hectares $(27.7 \%)$ for the first crop season, during the rainfall season, and 12.8 million hectares $(72.3 \%)$ for the second crop season, which is also known as "safrinha" and takes place after the harvest of early-soybean (IBGE, 2020). Corn farming has been considered a risky activity, especially during the first crop season, because of its high production cost and the risk of losses due to drought. In the state of Rio Grande do Sul, Brazil, the average production cost per hectare in the 2019/2020 harvest was R\$ 2,213.98, with seeds and fertilizers accounting for $28 \%$ and $42 \%$ of the variable production cost, respectively (CONAB, 2019).
Thus, considering that seeds and fertilizers account for over half of the variable production cost, technological innovations are sought to optimize the input usage and increase the efficiency of the production system. In recent years, seed drills have been equipped with a satelliteguided device that enables each row to be automatically and individually turned on and off by replacing the mechanical drive with hydraulic and electric actuators (Velandia et al., 2013). As a result, sowing overlap has ceased to be a problem in areas of agricultural production.

Overlapping areas generally occur at the ends of the plot, i.e., on field headlands, during maneuvering, or when avoiding obstacles (Corassa et al., 2018). The overlap potentially increases with greater seed drill widths (Luck et al., 2010). Furthermore, smaller and irregularly shaped areas also show increased sowing overlap (Velandia et al., 2013).

Sowing overlap results in more plants per area (duplication), promoting higher intraspecific competition for light, water, and nutrients (Sangoi, 2000; Argenta et al., 2001), thereby inducing crop productivity losses (Demétrio et al., 2008; Corassa et al., 2018). This is especially the case in modern corn hybrids, which are highly responsive to environmental conditions (Cardoso et al., 2012). Therefore, automatic section control technologies for seed drills have

\footnotetext{
${ }^{1}$ Universidade Federal de Santa Maria - Campus de Frederico Westphalen/ Frederico Westphalen - RS, Brasil.

${ }^{2}$ SLC Máquinas - John Deere/ Cruz Alta - RS, Brasil.

${ }^{3}$ Escola Superior de Agricultura "Luiz de Queiroz" - Universidade de São Paulo/ Piracicaba - SP, Brasil.
}

Area Editor: João Paulo Arantes Rodrigues da Cunha

Received in: 9-25-2019

Accepted in: 4-30-2020 
aroused the interest of farmers in terms of potential reduction in seed costs and productivity losses (Velandia et al., 2013; Larson et al., 2016).

As the adoption of corn crop technologies designed to enhance productivity has increased, this study was conducted to evaluate the effects of sowing overlap on yield and productivity components of three corn hybrids under highly productive farming systems. The tested hypothesis was that sowing overlap negatively affects corn grain production, regardless of the type of crop hybrid.

\section{MATERIAL AND METHODS}

\section{Area and experimental design}

The experiment was performed in a 52-hectare commercial grain production area located in Tupanciretã, Rio Grande do Sul, Brazil. The climate in this area is classified as Cfa (Peel et al., 2007), with well-distributed precipitation throughout the year and well-defined seasons. The soil was classified as an Argissolo Vermelho-Amarelo Eutrófico latossólico (Santos et al., 2018). The area was irrigated using a center pivot system. Notably, the cover crops that were grown in the area prior to the experiment were intercropped black oat (Avena strigosa Schreb.) and fodder radish (Raphanus sativus L.).

The experiment was conducted under a randomized block design in a $3 \times 2$ factorial scheme, resulting from the interaction of three corn hybrids (I, II, and III) and two sowing conditions (without sowing overlap - WOSO, and with sowing overlap - WSO). Four replications were performed, amounting to 24 experimental units in total.

\section{Agricultural operation setup of the experiment}

A mechanized set composed of an 8370R tractor (John Deere, Montenegro, Brazil), equipped with a motor of $272 \mathrm{~kW}$ (370 HP) rated power (according to the manufacturer), as well as a DB-50 precision seed drill
(John Deere, Horizontina, Brazil) with 33 rows, spaced $0.45 \mathrm{~m}$ from each other, and equipped with electric clutches configured for a 16-section automatic cut-off, were used for the experiment.

Sowing was conducted by planting 84,000 seeds per hectare. Two guidance directions, towards $190^{\circ}$ and $308^{\circ}$, and a pivot pattern were set up for automatic guidance. Variable-rate fertilization was performed based on the chemical analysis of the soil and the CQFS-RS/SC (2016) recommendations. The experimental area was uniformly irrigated at a single depth during the crop cycle, as needed.

The corn hybrids used in the experiment were: Hybrid I. AG 9025 (Agroceres $^{\circledR}$ ), which has a good response to management and technology, and is prescribed for the beginning of the sowing window (Sementes Agroceres, 2019); Hybrid II. 2A401 (Dow AgroScience ${ }^{\circledR}$ ), an early-cycle hybrid with high productivity and great performance in dryland farming (Dow Sementes, 2016); and Hybrid III. 30F53 (DuPont Pioneer ${ }^{\circledR}$ ), an early-cycle hybrid launched in 2002, able to reach high productivity, and recommended for both the beginning and the middle of the sowing window (Pioneer Sementes, 2019). The proportion of the experimental area cultivated with each hybrid was of 56\% for AG 9025 (Hybrid I), 21\% for 2A401 (Hybrid II), and 23\% for 30F53 (Hybrid III).

\section{Data acquisition}

Overlapping was determined during sowing by interpolating areas where the automatic shut-off control of the seed drill section was activated and deactivated, resulting in areas without and with sowing overlap, respectively. Data from the GS3 2630 seed monitor were imported to the Apex ${ }^{\circledR}$ software in the shapefiles format (.shp) and, subsequently, to the AutoCAD ${ }^{\circledR}$ software, which enabled the calculation of the total overlapped sown area corresponding to the predefined sowing direction (Figure 1).

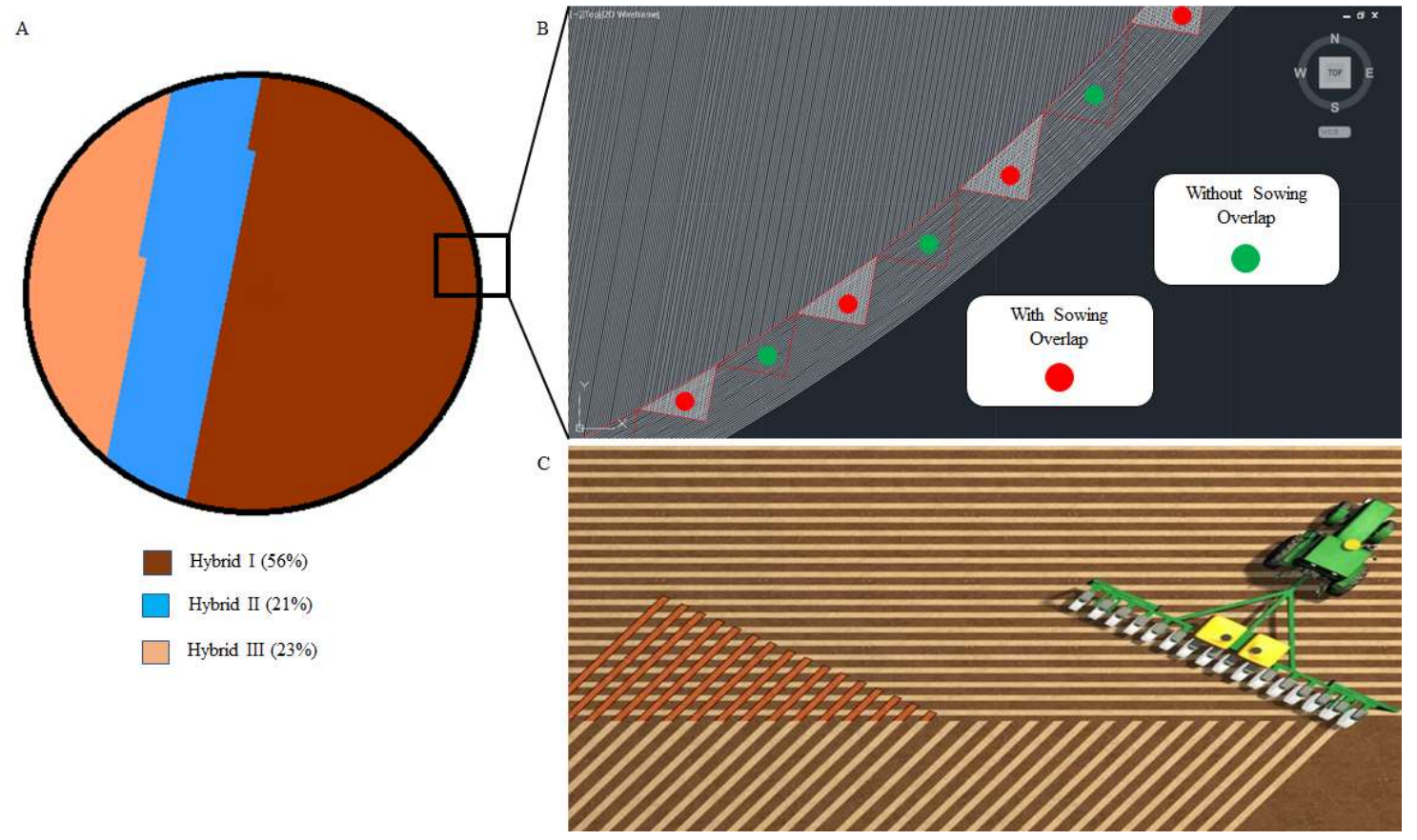

FIGURE 1. Schematic representation of the experiment: final proportion of the experimental area cultivated with each of the corn hybrids (A), areas without sowing overlapping interspersed with areas with sowing overlapping (B), representation of the automatic control of section shutdown of the seeder deactivated and activated, during the sowing operation (C). 
In WOSO and WSO areas, $3.00 \times 1.35 \mathrm{~m}$ plots (three sowing lines) were delimited and the number of plants per hectare was quantified for each condition by counting the total number of plants per plot. The number of cobs per hectare, total cob length, the number of grains per cob, the thousand grain weight, and grain productivity were determined during harvest, which was manually performed in the experimental area. Notably, the grain productivity values were corrected for $13 \%$ humidity.

\section{Data analysis}

After evaluation, data were analyzed for normality and homoscedasticity using the Shapiro-Wilk test $(p>0.05)$ and data transformation was found unnecessary. A variance analysis was performed $(p<0.05)$ to test the effects of sowing overlap and hybrids on productivity parameters. In case of significance (F-test $p<0.05)$, means were compared with Tukey's test $(\mathrm{p}<0.05)$, using the
Statistical Analysis System - SAS v.9.3 software (SAS Inc., Cary, USA).

\section{RESULTS AND DISCUSSION}

The overlap area accounted for 1.33 hectares, representing $2.54 \%$ of the total experiment area. These results are similar to those reported by Corassa et al. (2018), who obtained a 5.5\% average overlap in 128 plots. Velandia et al. (2013) evaluated 52 plots and observed overlap area variations ranging from $0.1 \%$ to $15.5 \%$, depending on the plot shape.

The variance analysis revealed a factor interaction effect between the thousand grain weight and total cob length, while both the number of cobs per hectare and productivity presented isolated significance for sowing conditions and hybrids (Table 1). The number of plants per hectare and the number of grains per cob were only affected by sowing conditions (Table 1).

TABLE 1. Summary of the ANOVA (F value) number of plants per hectare (NPH), number of cobs per hectare (NCH), total cob length (TCL), number of grains per cob (NGC), thousand grain weight (TGW) and productivity (P) parameters.

\begin{tabular}{lccccccc}
\hline \multirow{2}{*}{ Sources of variation } & \multirow{2}{*}{ Degrees of freedom } & \multicolumn{7}{c}{ Average squares } \\
\cline { 3 - 8 } & & $\mathrm{NPH}$ & $\mathrm{NCH}$ & $\mathrm{TCL}$ & $\mathrm{NGC}$ & $\mathrm{TGW}$ & $\mathrm{P}$ \\
\hline \multirow{3}{*}{ Hybrid $(\mathrm{H})$} & 1 & $542.42^{* *}$ & $350.98^{* *}$ & $512.95^{* *}$ & $22.23^{* *}$ & $52.31^{* *}$ & $10.91^{* *}$ \\
$\mathrm{~S} \mathrm{x} \mathrm{H}$ & 2 & 3.16 & $4.33^{*}$ & $59.44^{* *}$ & 2.75 & $125.94^{* *}$ & $24.41^{* *}$ \\
$\mathrm{CV}(\%)$ & 2 & 0.60 & 1.56 & $7.71^{* *}$ & 0.98 & $11.50^{* *}$ & 3.14 \\
\hline
\end{tabular}

$*$ and $* *$ represent $\mathrm{p}<0.05$ and $\mathrm{p}<0.01$, respectively.

Areas with sowing overlap presented a $92 \%$ higher number of plants per hectare when compared with areas without overlap (Figure 2). These numbers are higher than those reported by Corassa et al. (2018), who obtained a plant density $78 \%$ higher in areas without overlap control than in those with overlap control.

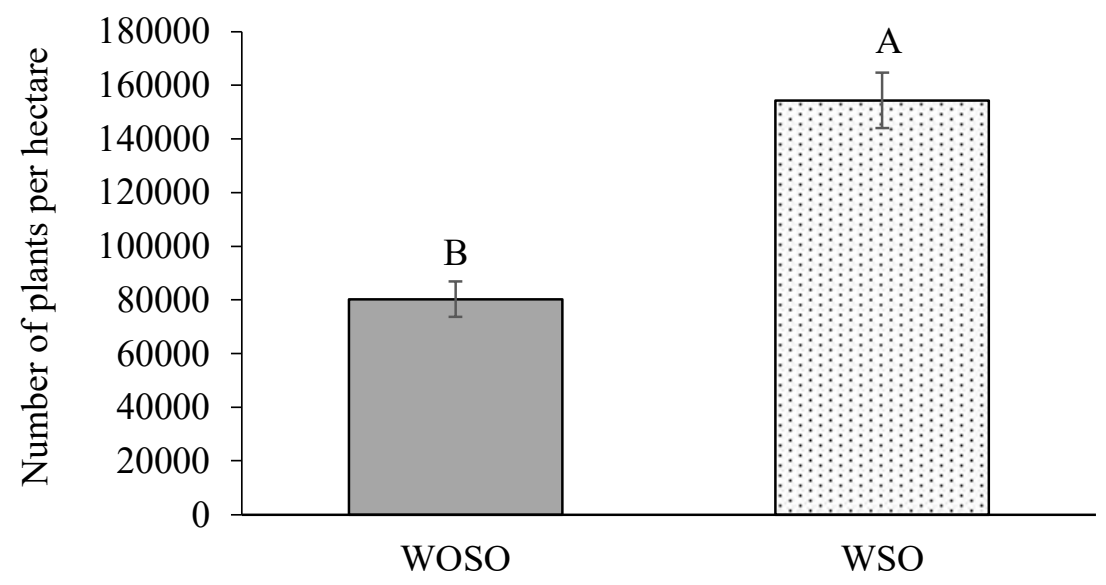

* Means followed by the same capital letter within each sowing condition do not differ by the Tukey test $(\mathrm{p}<0.05)$.

FIGURE 2. Number of plants per hectare depending on sowing conditions (without and with sowing overlap - WOSO and WSO).

Sowing overlap induced reductions of 35,31 , and $30 \%$ in the total cob length of hybrids I, II, and III, respectively (Figure 3A). Notably, the longer total cob length of hybrid II under conditions without overlap did not result in a higher thousand grain weight (Figure 3B). On the contrary, hybrids I and III presented higher thousand grain weights under conditions without sowing overlap. Furthermore, hybrid I presented a higher thousand grain weight compared to the other hybrids, regardless of sowing overlap, which can be explained by its genetic superiority. 

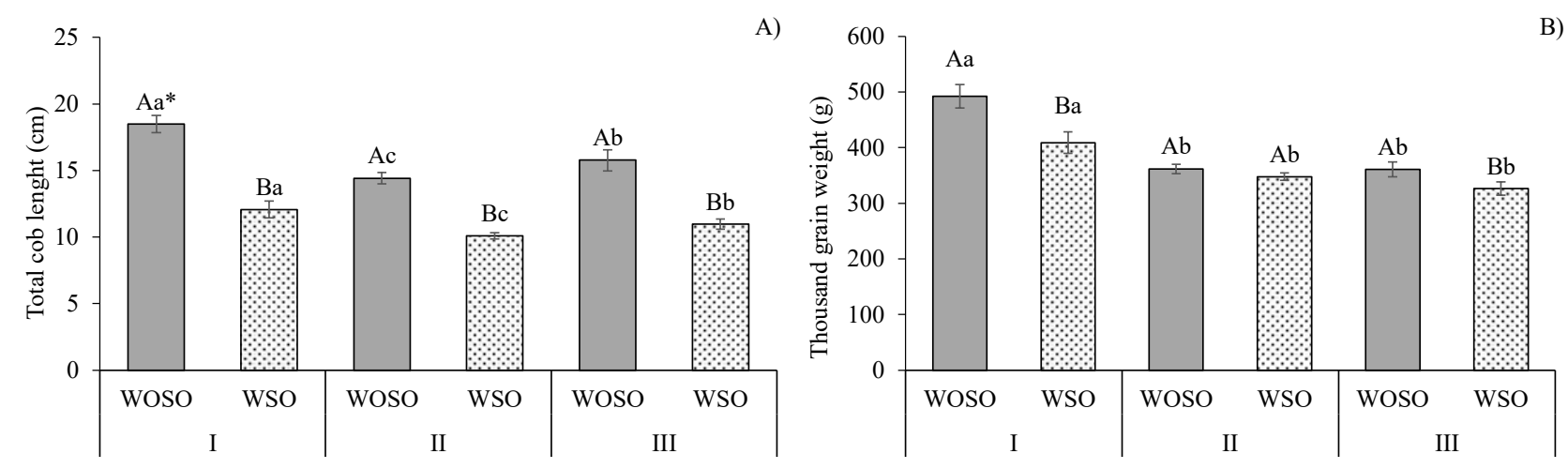

* Means followed by the same capital letter within each corn hybrid and lowercase letter within each sowing condition do not differ by Tukey's test $(\mathrm{p}<0.05)$.

FIGURE 3. Total cob length (A) and thousand grain weight (B) depending on sowing conditions (without and with sowing overlap - WOSO and WSO) for the three corn hybrids (I, II and III).

The higher plant density induced by sowing overlap increases the intraspecific competition for water and nutrients, resulting in the decrease in cob length, the translocation of photoassimilates to grains, and a consequent decrease in grain weight (Sangoi, 2000; Argenta et al., 2001; Dourado Neto et al., 2003).

Hybrid I presented a lower number of cobs per hectare compared to hybrid II, while hybrid III did not significantly differ from the other two hybrids (Figure 4A). Areas with overlap obtained $77 \%$ more cobs per hectare than did areas without overlap (Figure 4B), which is due to the overpopulation of plants per hectare as a consequence of the sowing overlap (Figure 2). However, a higher number of cobs did not result in productivity gains (Figure 4D).

Despite the lower number of cobs per hectare, hybrid I presented a productivity $21 \%$ higher than that of the other hybrids (Figure 4C). Areas without sowing overlap (Figure 4D) presented a productivity $13 \%$ higher than that of the overlap areas $\left(14,662 \mathrm{~kg} \mathrm{ha}^{-1}\right.$ and 12,997 $\mathrm{kg} \mathrm{ha}^{-1}$, respectively).

A)
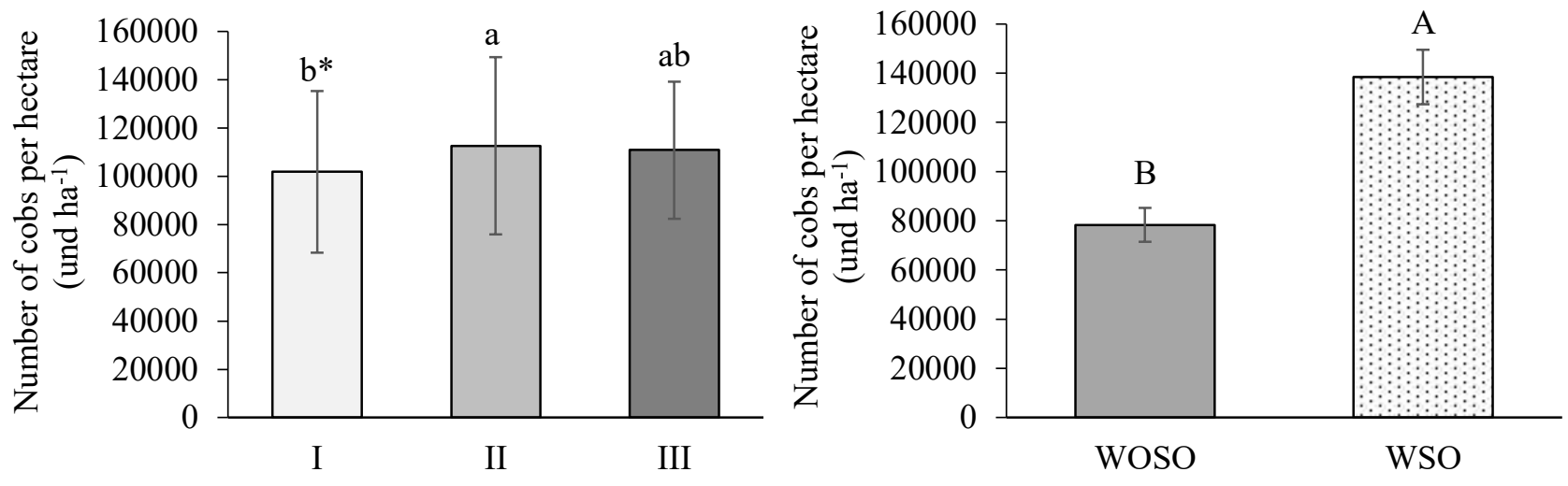

C)
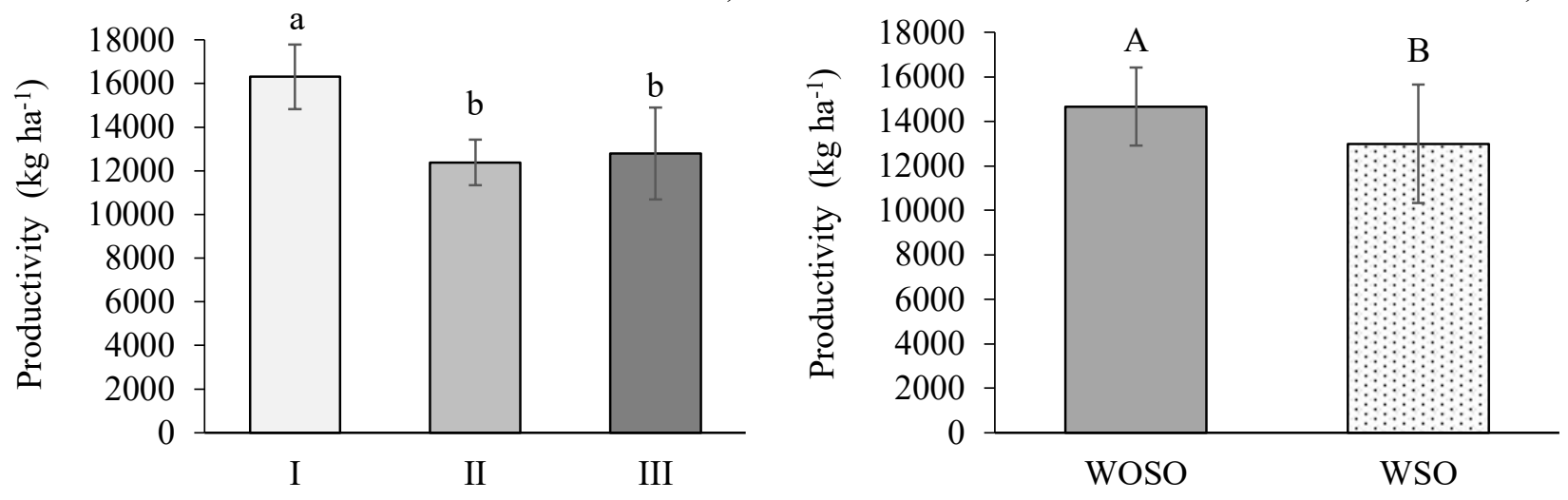

*Means followed by the same lowercase letter within each corn hybrid and capital letter within each sowing condition do not differ by Tukey's test $(\mathrm{p}<0.05)$.

FIGURE 4. Number of cobs per hectare (A and B) and productivity (C and D) depending on corn hybrids (I, II and III) (left) and on sowing conditions (without and with sowing overlap - WOSO and WSO) (right). 
The results corroborate the findings of Corassa et al. (2018), who found respective reductions of $8 \%$ and $2 \%$ in corn and soybean productivity due to sowing overlap in the field. According to Assefa et al. (2016), corn grain productivity decreases when plant density is above the optimum of the plant.
Increased corn plant density per area unit results in a higher number of cobs per hectare (Figure 4B). However, those cobs are underdeveloped and present fewer grains (Figure 5).

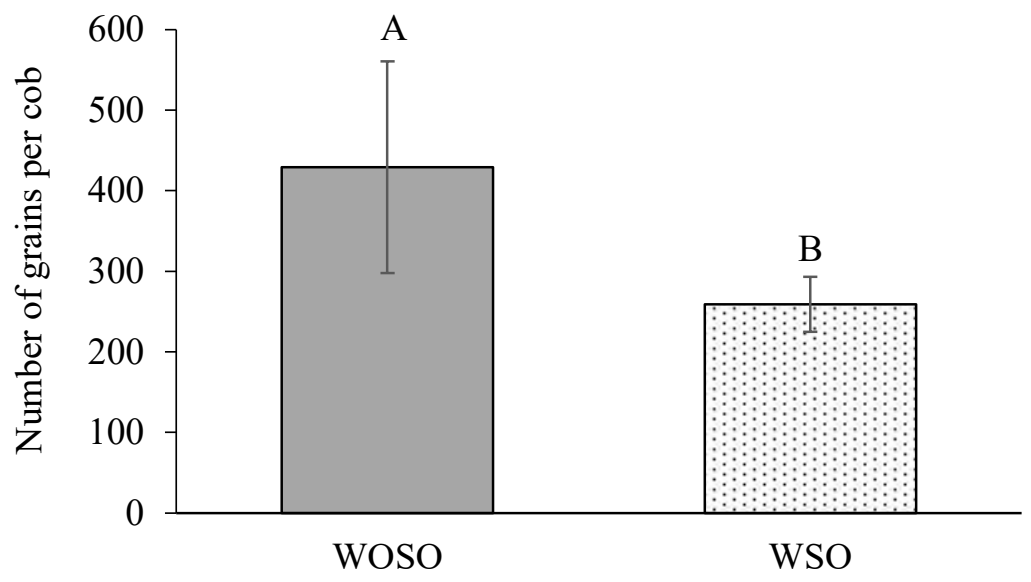

*Means followed by the same capital letter within each sowing condition do not differ by the Tukey test $(\mathrm{p}<0.05)$.

FIGURE 5. Number of grains per cob depending on sowing conditions (without and with sowing overlap - WOSO and WSO).

In general, the number of grains per cob decreases as plant density per hectare becomes greater (Kopper et al., 2017). Increases in population density result in intraspecific competition, decreasing the availability of resources and reducing the number of grain rows per cob (Brachtvogel et al., 2009). Furthermore, the increased number of plants per hectare may result in a nitrogen deficit, reducing the number of grains per cob, especially in the top portion of the cob, which does not develop properly regardless of regular egg fertilization (Sangoi, 2000).

\section{CONCLUSIONS}

Areas with sowing overlap have an increased number of plants per hectare, which results in plants with a reduced productive potential. On the contrary, the use of embedded technology for automatic section control in seed drills minimizes sowing overlap, hence maintaining an adequate plant density and resulting in longer cobs with a higher number of grains.

Areas without sowing overlap presented a grain productivity that was $13 \%$ higher than that of areas with sowing overlap. Notably, performance was the greatest for hybrid I.

The results of this study support the effectiveness of the automatic section control in seed drills, which decreases the required number of seeds (reduction of production costs) and avoids productivity losses in areas with overlap. Despite these benefits, it is worth considering the size of the cultivated area and calculating the return on investment, as well as verifying the economic feasibility of using this type of technology.

\section{REFERENCES}

Argenta G, Silva PRF, Sangoi L (2001) Maize plant arrangement: Analysis of the state of the art. Ciência Rural 31(6):1075-1084. Available:

https://www.scielo.br/pdf/cr/v31n6/a27v31n6.pdf. DOI: https://doi.org/10.1590/S0103-84782001000600027
Assefa Y, Vara Prasad PV, Carter P, Hinds M, Bhalla G, Schon R, Jeschke M, Paszkiewicz S, Ciampitti IA (2016) Yield Responses to Planting Density for US Modern Corn Hybrids: A Synthesis-Analysis. Crop Science 56(5):2802-2817. Available: https://acsess.onlinelibrary.wiley.com/doi/pdf/10.2135/cropsci2 016.04.0215. DOI:

https://doi.org/10.2135/cropsci2016.04.0215

Brachtvogel EL, Pereira FRS, Cruz SCS, Bicudo SJ (2009) Maize plant densities in conventional and equidistant plant spacing. Ciência Rural 39(8):2334-2339. Available: https://www.scielo.br/pdf/cr/v39n8/a340cr1474.pdf. DOI: https://doi.org/10.1590/S0103-84782009005000193

Cardoso MJ, Carvalho HWL, Rocha LMP, Pacheco CAP, Guimarães LJM, Guimarães PEO, Parentony SN, Oliveira IR (2012) Maize-cultivar identification based on phenotypestability analysis in the Mid-Northern region of Brazil. Revista Ciência Agronômica 43(2):346-353. Available: https://www.scielo.br/pdf/rca/v43n2/a18v43n2.pdf. DOI: https://doi.org/10.1590/S1806-66902012000200018

CQFS-RS/SC - Comissão de Química e Fertilidade do Solo - RS/SC (2016) Manual de calagem e adubação para os estados do Rio Grande do Sul e de Santa Catarina. Porto Alegre, Sociedade Brasileira de Ciência do Solo, 376p.

CONAB - Companhia Nacional de Abastecimento (2019) Planilhas de custos de produção - culturas de $1^{a}$ Safra. Available: https://www.conab.gov.br/info-agro/custos-deproducao/planilhas-de-custo-deproducao/itemlist/category/406-planilhas-de-custos-deproducao-culturas-de-1-safra. Accessed: Apr 17, 2020.

Corassa GM, Amado TJC, Liska T, Sharda A, Fulton J, Ciampitti IA (2018) Planter Technology to Reduce Double-Planted Area and Improve Corn and Soybean Yields. Agronomy Journal 110(1):300-310. Available: https://acsess.onlinelibrary.wiley.com/doi/pdf/10.2134/agr onj2017.07.0380? casa token=rKPrCQ1MgNIAAAAA:wg 00CgSDStLy2cIHIt1pohXcvp_3Fj9PG2NMOlFt6vfcnqlr Qv0zkmXJFfMiiMMkaVdERQyuEZL1awmG. DOI: https://doi.org/10.2134/agronj2017.07.0380 
Demétrio CS, Fornasieri Filho D, Cazetta JO, Cazetta DA (2008) Performance of maize hybrids submitted to different row spacing and population densities. Pesquisa Agropecuária Brasileira 43(12):1691-1697. Available: https:/www.scielo.br/pdf/pab/v43n12/v43n12a08.pdf. DOI: https://doi.org/10.1590/S0100-204X2008001200008

Dourado Neto D, Palhares M, Vieira PA, Manfron PA, Medeiros SLP, Romano MR (2003) Distribution and population of plants and maize grain yield. Revista Brasileira de Milho e Sorgo 2(3):63-77. Available: http://rbms.cnpms.embrapa.br/index.php/ojs/article/view/7 2/pdf_342. DOI: https://doi.org/10.18512/19806477/rbms.v2n3p63-77

Dow Sementes (2016) Guia de sementes 2016. Available: http://msdssearch.dow.com/PublishedLiteratureDAS/dh_09 65/0901b803809657ef.pdf?filepath=br/pdfs/noreg/01305181.pdf\&fromPage=GetDoc. Accessed: Jun 17, 2019.

Farias MS, Schlosser JF, Martini AT, Bertollo GM, Alvez JV (2018) Operational and energetic performance of an agricultural tractor during harrowing operation. TECNOLÓGICA 22(2):213-216. Available:

https:/online.unisc.br/seer/index.php/tecnologica/article/vi ew/12125/7428. DOI:

https://doi.org/10.17058/tecnolog.v22i2.12125

IBGE - Instituto Brasileiro de Geografia e Estatística (2020) Indicadores IBGE: Levantamento Sistemático da Produção Agrícola - Estatística da Produção Agrícola março de 2020. Rio de Janeiro, IBGE, p82-85. Accessed: Apr 17, 2020.

Kopper CV, Meert L, Krenski A, Borghi WA, Oliveira Neto AM, Figueiredo AST (2017) Second season maize yield based on sowing speed and plant population density. Pesquisa Agropecuária Pernambucana 22(1):1-6. Available: https://pap.emnuvens.com.br/pap/article/view/pap.2017.003 /80. DOI: https://doi.org/10.12661/pap.2017.003

Larson JA, Velandia MM, Buschermohle MJ, Westlund SM (2016) Effect of field geometry on profitability of automatic section control for chemical application equipment. Precision Agriculture 17(1):18-35. Available: https://link.springer.com/content/pdf/10.1007/s11119-0159404-y.pdf. DOI: https://doi.org/10.1007/s11119-015-9404-y

Luck JD, Pitla SK, Shearer SA, Mueller TG, Dillon CR, Fulton JP, Higgins SF (2010) Potential for pesticide and nutrient savings via map-based automatic boom section control of spray nozzles. Computers and Electronics in Agriculture 70(1):19-26. Available:

https://www.sciencedirect.com/science/article/pii/S016816 9909001586?via\%3Dihub. DOI:

https://doi.org/10.1016/j.compag.2009.08.003
Miranda ACC, Veríssimo AM, Ceolin AC (2017)

Precision Agriculture: A Scielo Base Mapping. Revista Eletrônica de Gestão Organizacional 15(Ed especial):129137. Available:

https://periodicos.ufpe.br/revistas/gestaoorg/article/view/2 31252/26096. DOI: https://doi.org/10.21714/167918272017v15Ed.p129-137

Peel MC, Finlayson BL, McMahon TA (2007) Updated world map of the Köppen-Geiger climate classification. Hydrology and Earth System Sciences 11(5):1633-1644. Available: https://www.hydrol-earth-systsci.net/11/1633/2007/. DOI: https://doi.org/10.5194/hess11-1633-2007

Pioneer Sementes (2019) Híbridos de milho. Available: http://www.pioneersementes.com.br/milho/central-deprodutos/produtos/30f53. Accessed: Jun 17, 2019.

Sangoi L (2000) Understanding plant density effects on maize growth and development: An important issue to maximize grain yield. Ciência Rural 31(1):159-168. Available:

https://www.scielo.br/pdf/cr/v31n1/a27v31n1.pdf. DOI: 10.1590/S0103-84782001000100027

Santi AL, Amado TJC, Eitelwein MT, Cherubin MR, Silva RF, Da Ros CO (2013) Definition of yield zones in areas managed with precision agriculture. Revista Brasileira de Ciências Agrárias 8(3):510-515. Available:

http://www.agraria.pro.br/ojs-

2.4.6/index.php?journal $=$ agraria $\&$ page $=$ article $\&$ op $=$ view $\&$ path $\% 5 \mathrm{~B} \% 5 \mathrm{D}=$ agraria_v8i3a2489\&path $\% 5 \mathrm{~B} \% 5 \mathrm{D}=587$.

DOI: https://doi.org/10.5039/agraria.v8i3a2489

Santos HG, Jacomine PKT, Anjos LHC, Oliveira VA, Lumbreras JF, Coelho MR, Almeida JA, Araujo Filho JC, Oliveira JB, Cunha TJF (2018) Sistema Brasileiro de Classificação de solos. Brasília, Embrapa Solos, 356p.

Sementes Agroceres (2019) AG 9025. Available: http://www.sementesagroceres.com.br/pages/Produto_AG _9025.aspx. Accessed: Jun 17, 2019.

Velandia M, Buschermohle M, Larson JA, Thompson NM, Jernigan BM (2013) The economics of automatic section control technology for planters: A case study of middle and west Tennessee farms. Computers and Electronics in Agriculture 95:1-10. Available:

https:/www.sciencedirect.com/science/article/pii/S016816 9913000562?via\%3Dihub. DOI:

https://doi.org/10.1016/j.compag.2013.03.006 